gonadotrophic substance of pregnant mares' serum and for the lactogenic (crop-gland stimulating) substance of the anterior lobe of the pituitary gland. The former standard has been prepared from substantial amounts of material generously provided by five manufacturing firms in four different countries, and the latter from material supplied by seven manufacturing firms and two research institutes in five countries. In the case of each standard the individual samples were examined by members of the Conference and a suitable mixture was then made to serve as the respective international standard, and finally dispensed in the form of tablets which have been packed in sealed tubes. In the case of each standard, each tablet contains approximately 100 international units.

Tie international standard for the gonadotrophic substance of pregnant mares' serum is dispensed in the form of $25 \cdot \mathrm{mgm}$. tablets, each sealed tube containing ten of the tablets, and the international unit has been defined as the specific gonadotrophic activity. contained in $0.25 \mathrm{mgm}$. of the standard preparation. The international standard for prolactin is dispensed in the form of $10-\mathrm{mgm}$. tablets, each sealed tube containing ten of the tablets, and the international unit has been defined as the specific activity contained in $0.1 \mathrm{mgm}$. of the standard preparation. As in the case of the international standards for other hormones, drugs and vitamins, the above international standards aro held, on behalf of the Health Organisation of the League of Nations, at the National Institute for Medical Research, Hampstead, London, N.W.3, and are distributed therefrom to national control centres established in other countries for local distribution to laboratories, institutes and research workers, and to workers in other countries in which the establishment of national control centres has not yet been completed. With regard to the supply of these new standards to those requiring them in the United Kingdom, applications should be made to the Department of Biological Standards, National Institute for Medical Research, Hampstead, London, N.W.3.

\section{Standardizing Genetical Symbolism}

AT the International Congress of Genetics held at Ithaca, N.Y., in 1932, it was resolved that the genetical societies of all countries be asked to co. operate in preparing recommendations regarding the problem of standardizing genetical symbolism, in order to discuss them at the next International Genetical Congress. Prof. Tine Tammes (Groningen), who was appointed to take charge of this work; produced a preliminary report in conjunction with Dr. H. de Haan and then turned over the task to the International Union of Biological Sciences. This body, together with the International Institute for Intellectual Co-operation at Paris, convoked a meeting of delegates from various countries, which was held in the rooms of the Linnean Society of London on August 14-15, 1939, with Prof. II. J. Sirks (Groningen) as chairman. The delegates were Dr.
A. Establier and Miss N. Nicolsky (from the I.I.I.C. in Paris), Prof. O. Winge (Denmark), Dr. B. Ephrussi (Franco), Prof. H. Nachtsheim (Germany), Prof. R. R. Gates, Prof. J. B. S. Haldano and MIr. A. E. Watkins (Great Britain), Prof. K. v. Körösy (Hungary), Dr. K. Ramiah and Dr. S. N. Venkatraman (India), Prof. II. J. Sirks and Dr. S. J. Wellensiek (Holland), Prof. O. L. Mohr (Norway), Prof. MI. Skalinska (Poland), Dr. O. Tedin (Sweden), Prof. F. Baltzer, Prof. A. Ernst and Prof. E. Hadorn (Switzerland), and Prof. E. W. Lindstrom (U.S.A.). The delegates from Belgium, Finland, Italy and Japan were unable to attend. A preliminary series of rules for the symbolizing of genes and chromosome aberrations was drawn up at this meeting.

\section{Science and Ethics}

In the Scientific Monthly of October, Prof. E. G. Conklin discusses the question: "Does science afford a basis for ethics? The highest level of human development, he urges, is attained when purpose and freedom, joined to social emotions, training and habits, shape behaviour not only for personal but also for social satisfactions. Society, no less than the individual, is seeking satisfactions, and when all these things combine, we have what we call ethics, or the science of right conduct. Science, he considers, affords a sound basis for ethics in spite of the fact that it is regarded as natural rather than supernatural in origin and dovelopment. With increasing knowledge of Nature and man, many codes have been shown to be unreasonable and unethical, and science has helped to replace them by more rational and humane ones. Science is knowledgo of Nature and of man, and ethics being dependent on such knowledge it is impossible to divorce ethics from science. Science did not create Nature or man or ethics, and cannot be held responsible for their imperfections. It is as absurd to attribute human greed, aggression, hate and war to science as it would be to hold it responsible for hurricanes, earthquakes or pestilences. Because science regards ethics as a natural phenomena, it can hope to determine the causes of unethical behaviour and attempt to improvo ethics by controlling these causes.

Prof. Conklin thus believes that progress in tho control of social disorders should be possible in the same way as in the control of bodily diseases. Science has helped to make war so terrible that sano people everywhere fear and shun it. More indirectly, science can investigate the causes of war and show how they can bo removed, for war and social disorders in general can be cured only as bodily diseases are, by controlling their causes. The main hope for human peace and progress lies in the cultivation of habits that make for peace and progress, especially in the leaders of the nations. There can be no final solution of the problems which threaten the very existence of civilization except through the cultivation of a wider and moro generous form of ethics. Hope for the future rests in the co-operation of science, education and religion. 